\title{
Analysis of Mechanical Properties for the Heat Resistant Co-Modified 12 and 9\% Cr Steels
}

\author{
A. E. Fedoseeva ${ }^{a, *}$, I. S. Nikitin ${ }^{a}$, N. R. Dudova ${ }^{a}$, and R. O. Kaibyshev ${ }^{a}$ \\ ${ }^{a}$ Belgorod National Research University, Belgorod, 308015 Russia \\ *e-mail:fedoseeva@bsu.edu.ru \\ Received June 3, 2020; revised August 4, 2020; accepted August 11, 2020
}

\begin{abstract}
An analysis of mechanical properties has been performed for $12 \% \mathrm{Cr}$ and $9 \% \mathrm{Cr}$ steels by means of tension tests at 20 and $650^{\circ} \mathrm{C}$ and yield tests at $650^{\circ} \mathrm{C}$ and applied stresses of $200-100 \mathrm{MPa}$ with a step of $20 \mathrm{MPa}$. The yield strength and ultimate tensile strength of the $12 \% \mathrm{Cr}$ steel are, correspondingly, 614 and $710 \mathrm{MPa}$ at $20^{\circ} \mathrm{C}$ and 365 and $390 \mathrm{MPa}$ at $650^{\circ} \mathrm{C}$. At both temperatures, the strength properties of the $12 \% \mathrm{Cr}$ steel under tension are better than for the $9 \% \mathrm{Cr}$ steel due to higher values of contributions from solid-solution hardening (+30 MPa) and substructural hardening (+23 $\mathrm{MPa})$ to the room-temperature yield strength. The analysis of creep properties shows that the time to fracture at high stresses for the $12 \% \mathrm{Cr}$ steel is much longer than for the $9 \% \mathrm{Cr}$ steel due to a more prolonged transient creep stage and, at low applied stresses, there is almost no difference in the creep behavior of the $12 \% \mathrm{Cr}$ and $9 \% \mathrm{Cr}$ steels. The $1 \%$ creep limit estimated from the empirical dependence between the stress and the time required to attain the strain with a degree of $1 \%$ for the $12 \% \mathrm{Cr}$ steel is $82 \mathrm{MPa}$, being comparable with the $1 \%$ creep limit of the $9 \% \mathrm{Cr}$ steel.
\end{abstract}

Keywords: refractory steel of martensite class, tension tests, hardening mechanisms, creep, creep limit DOI: $10.1134 / \mathrm{S} 0031918 X 20120054$

\section{INTRODUCTION}

The $9 \% \mathrm{Cr}$ steels are suitable materials for boilers, steam pipelines, and turbine rotors of coal-fired thermal power plants because of their more stable structure during the process of creep compared to the $12 \%$ $\mathrm{Cr}$ steels [1]. The optimal steel for boiler tubes and steam pipelines is currently considered to be European steel P92 $(0.1 \mathrm{C}-0.05 \mathrm{~N}-9 \mathrm{Cr}-1.8 \mathrm{~W}-0.6 \mathrm{Mo}-0.24 \mathrm{~V}-$ $0.07 \mathrm{Nb}$ ), which allows prolonged operation at temperatures up to $600^{\circ} \mathrm{C}$ and short-life service up to $620^{\circ} \mathrm{C}$ [2-7]. All the new high-chromium steels are developed on the basis of the steel P92 by modifying its chemical composition [1,3-9]. The cobalt addition of $3 \%$ to the steel P92 essentially increases its long-term strength from 72 to $86 \mathrm{MPa}$, which is calculated with the Larson-Miller parameter at a test temperature of $650^{\circ} \mathrm{C}$ on the basis of $100000 \mathrm{~h} \mathrm{[9].}$

However, the $9 \% \mathrm{Cr}$ steels are limited in application at temperatures above $630^{\circ} \mathrm{C}$ despite their high creep resistance. This is because the chromium content of less than $11 \%$ does not provide sufficient resistance to oxidation. The formation of wustite $\mathrm{FeO}$ at a temperature of nearly $637^{\circ} \mathrm{C}$ on the surface of parts manufactured of $9 \% \mathrm{Cr}$ steels necessitates a special operation of preliminary surface oxidation for the formation of a protective $\mathrm{Cr}_{2} \mathrm{O}_{3}$ oxide film, which prevents the surface from oxidation under operation $[1,10]$. To improve the resistance to oxidation, it is necessary to increase the chromium content up to $11-12 \%$, as the $11 \% \mathrm{Cr}$ steel requires no similar treatment; the refractory characteristics of the $11 \% \mathrm{Cr}$ steel provide its service at $650^{\circ} \mathrm{C}$ due to a dense chromium oxide layer, which is formed in a natural way on the surface of this steel and provides its high refractoriness in an overheated steam atmosphere $[1,6]$. However, the $12 \% \mathrm{Cr}$ steels demonstrate lower creep resistance characteristics compared with the $9 \% \mathrm{Cr}$ steels because of their microstructural instability under creep [1, 3-6].

To improve the microstructural stability of the $12 \%$ $\mathrm{Cr}$ steel under creep and, consequently, its creep resistance, the microstructural design of the $12 \% \mathrm{Cr}$ steel was developed on the basis of earlier studies [7-9, 11] by optimizing the content of its austenite and ferritestabilizing elements. An increase in the chromium content to $12 \%$ in the studied steel as necessary to improve the resistance to oxidation up to $650^{\circ} \mathrm{C}$ in combination with a low nitrogen content was compensated by increasing the concentration of substituting austenite-stabilizing elements, namely, the boron content was increased to $0.01 \%$ with the addition of surplus copper and tantalum to 1 and $0.07 \%$, respectively [11]. The corrected chemical composition of new steels has resulted in a $\delta$-ferrite content of less than $10 \%$ in steel [11]. An increase in the boron content must decelerate diffusion-controlled processes like the climb of dislocations and the coarsening of secondary phase particles by the Ostwald ripening 
Table 1. Chemical compositions of the studied $12 \% \mathrm{Cr}$ and $9 \% \mathrm{Cr}$ steels (in wt \%)

\begin{tabular}{c|c|c|c|c|c|c|c|c|c|c|c}
\hline Steel & $\mathrm{C}$ & $\mathrm{Cr}$ & $\mathrm{Co}$ & $\mathrm{Mo}$ & $\mathrm{W}$ & $\mathrm{V}$ & $\mathrm{Cu}$ & $\mathrm{Nb}$ & $\mathrm{B}$ & $\mathrm{N}$ & $\mathrm{Ta}$ \\
\hline $12 \% \mathrm{Cr}$ & 0.11 & 11.4 & 3.0 & 0.6 & 2.5 & 0.23 & 0.76 & 0.04 & 0.01 & 0.003 & 0.07 \\
$9 \% \mathrm{Cr}$ & 0.12 & 9.3 & 3.1 & 0.4 & 2.0 & 0.23 & - & 0.06 & 0.005 & 0.05 & - \\
\hline
\end{tabular}

$[1,5]$. The addition of copper is caused by the possible formation of nanoclusters of $3-5 \mathrm{~nm}$ in size under tempering, and these nanoclusters, being nucleation sites of Laves phases precipitating under creep, provoke a more finely-dispersed distribution of this phase $[1,5]$. The addition of tantalum must provide the three-phase separation of $M e(\mathrm{C}, \mathrm{N})$ carbonitrides into niobium-rich $\mathrm{Nb}(\mathrm{C}, \mathrm{N})$, vanadium-rich $\mathrm{V}(\mathrm{C}, \mathrm{N})$, and tantalum-rich $\mathrm{Ta}(\mathrm{C}, \mathrm{N})$ particles to decelerate the substitution of nanosized $M e(\mathrm{C}, \mathrm{N})$ particles by coarse Z-phase particles [12]. The complex effect of the mentioned doping elements must improve the microstructural stability of the $12 \% \mathrm{Cr}$ steel and, consequently, increase its creep resistance. The objective of this study was to perform the analysis of mechanical properties under tension and creep at $650^{\circ} \mathrm{C}$ for the studied Co-modified $12 \% \mathrm{Cr}$ steel in comparison with the 9\% Cr steel.

\section{METHOD}

The chemical compositions of the $12 \% \mathrm{Cr}$ and $9 \%$ $\mathrm{Cr}$ steels are given in Table 1 . The $12 \% \mathrm{Cr}$ steel was melted in Institut für Eisenhüttenkunde (IEHK) (Aachen, Germany) in a vacuum induction furnace. The 9\% Cr steel was cast in NPO Central Research Institute of Mechanical Engineering Technology (Moscow, Russia) in a high-frequency induction furnace. The ingots were reforged into blanks shaped as bars of square cross section with a square side of $20 \mathrm{~mm}$ by free forging within a temperature range from 1150 to $900^{\circ} \mathrm{C}$. The thermal treatment of the $12 \% \mathrm{Cr}$ and $9 \% \mathrm{Cr}$ steels consisted in normalization from 1070 and $1050^{\circ} \mathrm{C}$ with further tempering at 770 and $750^{\circ} \mathrm{C}$ for $3 \mathrm{~h}$, respectively. Tension tests were performed on plane specimens with a working part length of $35 \mathrm{~mm}$ and a $7 \times 3-\mathrm{mm}^{2}$ cross section surface area at room temperature and a temperature of $650^{\circ} \mathrm{C}$ and a strain rate of $2 \mathrm{~mm} / \mathrm{min}$. The plane specimens with a working part length of $25 \mathrm{~mm}$ and a $7 \times 3-\mathrm{mm}^{2}$ cross section surface area and the cylindrical specimens with a working part length of $100 \mathrm{~mm}$ and a diameter of $10 \mathrm{~mm}$ were subjected to creep testing until failure at a temperature of $650^{\circ} \mathrm{C}$ and applied stresses ranged within 200-100 MPa with a step of $20 \mathrm{MPa}$ on an ATS2330 lever arm testing machine.

Structural studies were performed on a JEM JEOL-2100 transmission electron microscope (TEM) equipped with an INCA energy-dispersive attachment for determining the local chemical composition of particles and the solid solution. TEM foils were pre- pared by electrolytic polishing in the electrolyte containing 10-\% perchloric acid in acetic acid. The size of laths/subgrains was determined by the random linear intercept method with consideration for all the visible subboundaries from TEM images. The density of free dislocations inside laths/subgrains was estimated from the amount of points where dislocations emerged on the lower and upper surfaces of foil under the conditions of multibeam imaging with a high excitation vector. The methods were described in more detail in previous papers $[7-9,11]$.

\section{RESULTS AND DISCUSSION}

\section{Structure of the $12 \%$ Cr and 9\% Cr Steels after Thermal Treatment}

Normalizing with the following tempering led to the formation of a tempered martensite lath structure in both steels. The structural parameters of the studied $12 \% \mathrm{Cr}$ and $9 \% \mathrm{Cr}$ steels after thermal treatment are given in Table 2.

The TEM images of the initial structure of the studied 12\% $\mathrm{Cr}$ and 9\% Cr steels are shown in Fig. 1. The initial structure has a strict hierarchical character: prior austenite grains are divided into blocks, which in turn are divided into packets composed of martensite laths. The average transverse size of martensite laths is nearly $300 \mathrm{~nm}$ for both steels (Fig. 1, Table 2). A high density of dislocations $\left(\sim 2 \times 10^{14} \mathrm{~m}^{-2}\right)$ was revealed inside martensite laths of both steels (Table 2). Cr, Fe, and W-rich $\mathrm{Me}_{23} \mathrm{C}_{6}$ carbide particles are on the boundary of prior austenite grains, packets, blocks, and martensite laths (Fig. 1). The average size of $\mathrm{Me}_{23} \mathrm{C}_{6}$ particles on the boundaries of prior austenite grains and martensite laths is nearly 55 and $90 \mathrm{~nm}$ (Table 2) for the $12 \% \mathrm{Cr}$ and $9 \% \mathrm{Cr}$ steels, respectively. An essential structural distinction between the studied steels consists in the composition of $\mathrm{Me}(\mathrm{C}, \mathrm{N})$ carbonitrides. In the $9 \% \mathrm{Cr}$ steel, $\mathrm{Me}(\mathrm{C}, \mathrm{N})$ particles sustain two-phase separation into vanadium-rich $\mathrm{V}(\mathrm{C}, \mathrm{N})$ particles with an average size of $20 \mathrm{~nm}$ and niobium-rich $\mathrm{Nb}(\mathrm{C}, \mathrm{N})$ particles with an average size of $40 \mathrm{~nm}$ (Fig. 1b, Table 2). In the $12 \% \mathrm{Cr}$ steel, $\mathrm{M}(\mathrm{C}, \mathrm{N})$ particles also sustain two-phase separation into niobium-rich $\mathrm{Nb}(\mathrm{C}, \mathrm{N})$ particles with an average size of $40 \mathrm{~nm}$ and tantalumrich $\mathrm{Ta}(\mathrm{C}, \mathrm{N})$ particles with an average size of $50 \mathrm{~nm}$ (Fig. 1a, Table 2). The volume fraction of these particles was estimated by Thermo-Calc software (Table 2). The solid solution of the $12 \% \mathrm{Cr}$ steel after tempering at $770^{\circ} \mathrm{C}$ has the following composition (wt \%): $\mathrm{Cr}$, 10.5; Co, 3.0; W, 2.1; Mo, 0.5; V, 0.2. The composition 
Table 2. Structural parameters of the $12 \% \mathrm{Cr}$ and $9 \% \mathrm{Cr}$ steels after thermal treatment

\begin{tabular}{l|c|c}
\hline \multicolumn{1}{c|}{ Parameters } & $12 \%$ Cr steel & $9 \%$ Cr steel \\
\hline Size of laths, $\mathrm{nm}$ & $0.29 \pm 0.05$ & $0.34 \pm 0.05$ \\
Number density of dislocations, $\mathrm{m}^{-2}$ & $2.0 \times 10^{14}$ & $2.0 \times 10^{14}$ \\
$\mathrm{Me}_{23} \mathrm{C}_{6}$ size, $\mathrm{nm}$ & $55 \pm 5$ & $90 \pm 5$ \\
$\mathrm{Me}_{23} \mathrm{C}_{6}$ content, vol \% & 2.25 & 1.96 \\
$\mathrm{Nb}(\mathrm{C}, \mathrm{N})$ size, $\mathrm{nm}$ & $40 \pm 5$ & $40 \pm 5$ \\
$\mathrm{Ta}(\mathrm{C}, \mathrm{N})$ size, $\mathrm{nm}$ & $50 \pm 5$ & - \\
$\mathrm{V}(\mathrm{C}, \mathrm{N})$ size, $\mathrm{nm}$ & - & $20 \pm 5$ \\
$\mathrm{Me}(\mathrm{C}, \mathrm{N})$ content, vol \% & 0.08 & 0.25 \\
\hline
\end{tabular}

of the solid solution of the $9 \% \mathrm{Cr}$ steel after tempering at $750^{\circ} \mathrm{C}$ is the following (wt \%): $\mathrm{Cr}, 8.2 ; \mathrm{Co}, 3.0$; $\mathrm{W}, 1.8$; Mo, 0.4 .

\section{Mechanical Properties under Tension}

The engineering tension curves measured for the studied $12 \% \mathrm{Cr}$ and $9 \% \mathrm{Cr}$ steels by uniaxial tension testing at room temperature and a temperature of $650^{\circ} \mathrm{C}$ are plotted in Fig. 2. The $12 \% \mathrm{Cr}$ steel demon-
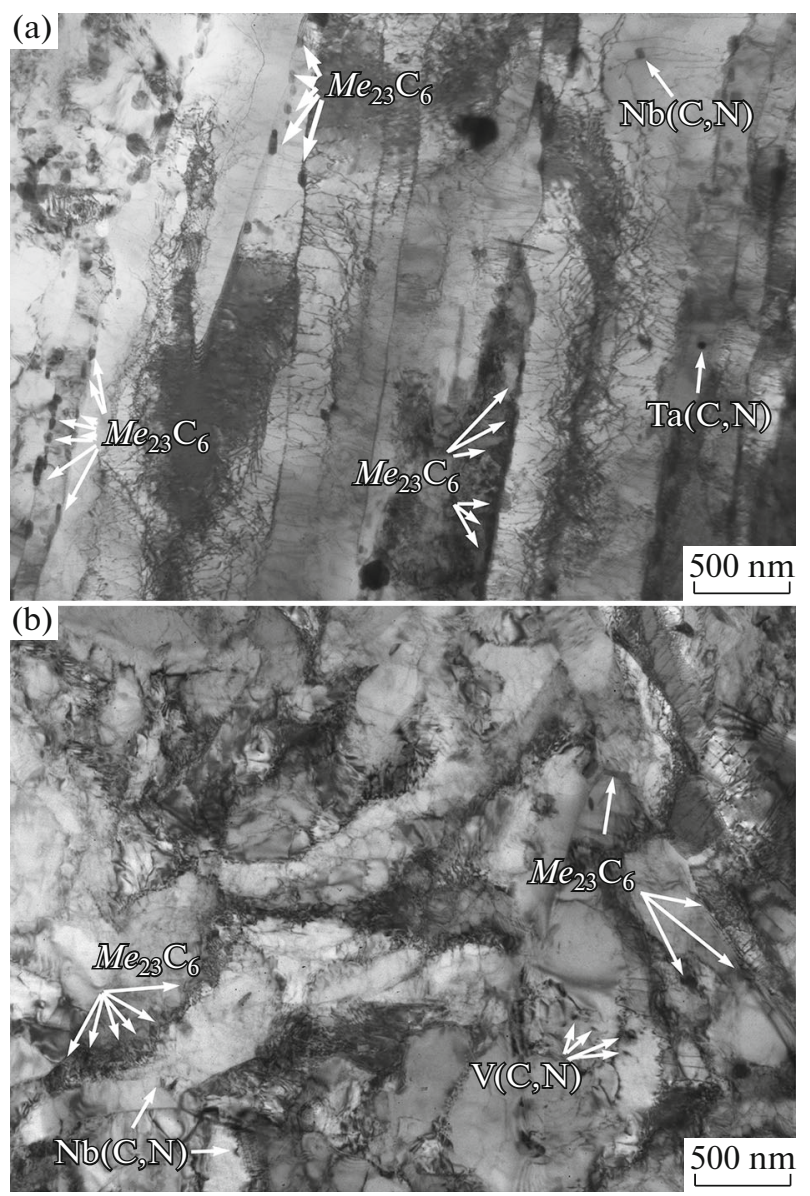

Fig. 1. Lath structure of troostomartensite in the studied (a) $12 \% \mathrm{Cr}$ and (b) \% Cr steels. strates an increase in the yield strength and ultimate tensile strength at both temperatures of testing in comparison with the $9 \% \mathrm{Cr}$ steel. Thus, the yield strength of the $12 \% \mathrm{Cr}$ steel is 10 and $23 \%$ higher than $\sigma_{0.2}$ if the $9 \% \mathrm{Cr}$ steel, and the ultimate tensile strength of the $12 \% \mathrm{Cr}$ steel is 1.5 and $20 \%$ higher than $\sigma_{u}$ of the $9 \%$ $\mathrm{Cr}$ steel after tension tests at 20 and $650^{\circ} \mathrm{C}$, respectively (Table 3).

\section{Hardening Mechanisms}

To ascertain the reasons for a higher strength of the $12 \% \mathrm{Cr}$ steel, the contributions of different hardening mechanisms to the overall strength were calculated in a similar way to the calculations [11]. The hardening types taken into account were the following:

-Hardening due to lattice friction $\sigma_{0}[13]$;

-Work hardening $\sigma_{\mathrm{WH}}[14]$;

-Solid-solution hardening by substitution elements $\sigma_{\mathrm{sS}}[15]$; [16];

-Dislocation hardening by the Taylor model $\sigma_{\text {disl }}$

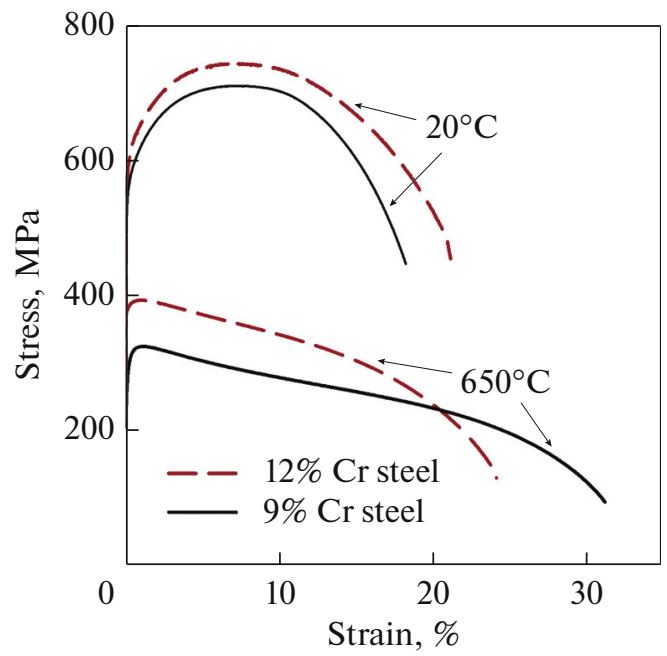

Fig. 2. Engineering tension curves of the studied $12 \% \mathrm{Cr}$ and $9 \%$ Cr steels.

No. $12 \quad 2020$ 
Table 3. Properties of the $12 \% \mathrm{Cr}$ and $9 \% \mathrm{Cr}$ steels under tension at 20 and $650^{\circ} \mathrm{C}$

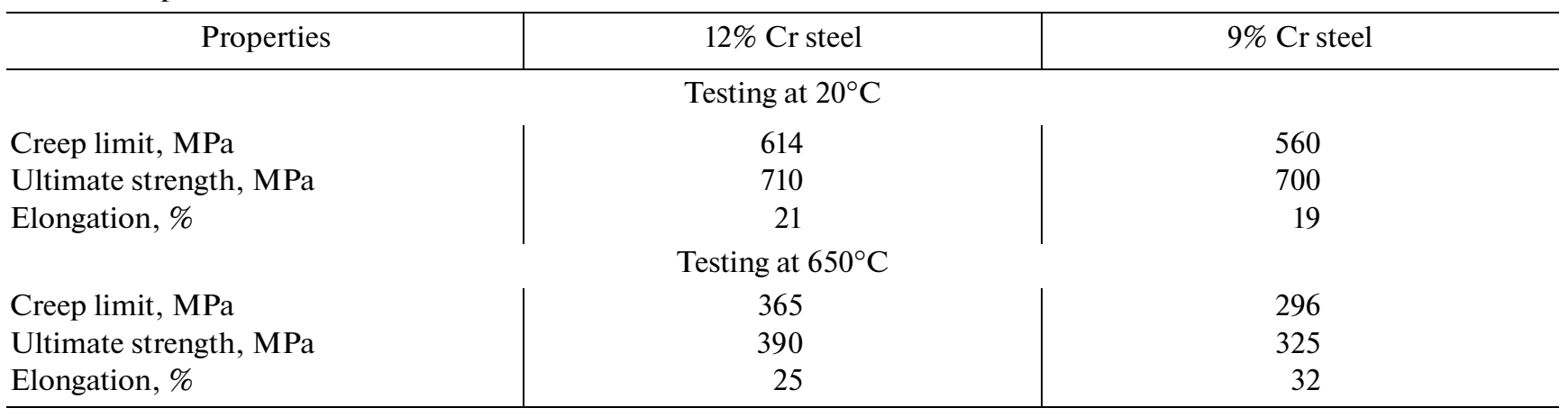

- Precipitation hardening according to the Orowan equation modified by F.J. Humphreys [17] under the assumption that all the particles are uniformly distributed over the matrix volume $\sigma_{\text {part }}$; and

- Substructural hardening by subgrains with lowangle boundaries by the Langford-Cohen model $\sigma_{\text {lath }}$ $[18,19]$.

The results of calculations are shown in Fig. 3.

The analysis of contributions from different hardening mechanisms to the overall strength has demonstrated that an increase in the yield strength of the $12 \%$ $\mathrm{Cr}$ steel under tension testing at room temperature in comparison with the $9 \% \mathrm{Cr}$ steel is provided by the growth of

- Solid-solution hardening due to a higher $\mathrm{Cr}, \mathrm{W}$, and Mo content in the solid solution after thermal treatment $(+30 \mathrm{MPa})$ and

- Substructural hardening by subgrains due to a smaller transvere size of martensite laths $(+23 \mathrm{MPa})$.

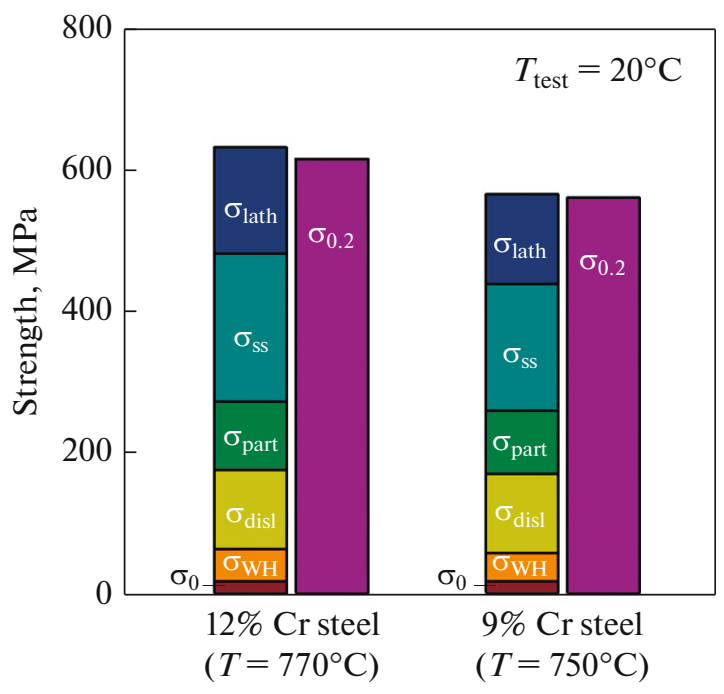

Fig. 3. Comparison of contributions from different hardening mechanisms to the overall strength of the studied $12 \% \mathrm{Cr}$ and $9 \% \mathrm{Cr}$ steels; $\sigma_{0.2}$ is the creep limit under tension at $20^{\circ} \mathrm{C}$.
Let us note that, despite the essential distinctions between the morphology and sizes of secondary phase particles in the $12 \% \mathrm{Cr}$ and $9 \% \mathrm{Cr}$ steels, the values of precipitation hardening in both steels are almost the same. In the $12 \% \mathrm{Cr}$ steel, a great contribution to precipitation hardening from fine $M e_{23} \mathrm{C}_{6}$ carbide particles compensates a smaller contribution from $\mathrm{Me}(\mathrm{C}, \mathrm{N})$ carbonitrides, whose low volumetric content is caused by a decrease in the nitrogen content (see Table 1 and 2). Hardening due to lattice friction forces, work hardening, and dislocation hardening also have the same values for both steels (Fig. 3).

\section{Mechanical Properties under Creep}

The dependences of the creep rate on the degree of strain and time at a temperature of $650^{\circ} \mathrm{C}$ and applied stresses of 180 and $100 \mathrm{MPa}$ for the studied $12 \% \mathrm{Cr}$ and $9 \% \mathrm{Cr}$ steels are shown in Fig. 4.

An essential distinction in the behavior of the studied steels is a more prolonged transitional stage of creep in the $12 \% \mathrm{Cr}$ steel at a high applied stress of $180 \mathrm{MPa}$ (Fig. 4b). At the transient creep stage, the creep rate continuously decreases as a result of hardening until a minimum creep rate is attained. This state corresponds to the establishment of equilibrium between the material hardening and softening processes $[1,3]$. Softening at the transient creep stage predominantly occurs due to the redistribution of dislocations $[1,3]$. A more highly doped solid solution and a smaller width of martensite laths in the $12 \% \mathrm{Cr}$ steel (Fig. 3) with a resulting increase in the tension strength in comparison with the $9 \% \mathrm{Cr}$ steel provide a higher resistance to the softening processes at the transient creep stage, as there are a greater number of obstacles for the motion and rearrangement of dislocations. Moreover, the minimum creep rate in the $12 \%$ $\mathrm{Cr}$ steel at a high stress is nearly two orders of magnitude lower than in the $9 \% \mathrm{Cr}$ steel (Figs. $4 \mathrm{a}$ and $4 \mathrm{~b}$ ). A decrease in the applied stress to $100 \mathrm{MPa}$ reduces the difference in the transient creep stage time and the minimum creep rate and, as a result, in the time to failure between the studied $12 \% \mathrm{Cr}$ and $9 \% \mathrm{Cr}$ steels. This is likely to be due to the elimination of advantages in the hardening of the $12 \% \mathrm{Cr}$ steel with an increase 
(a)

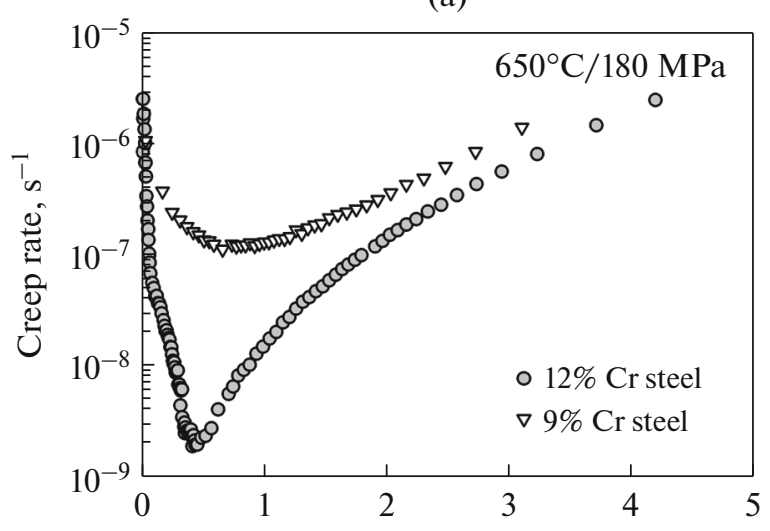

(c)

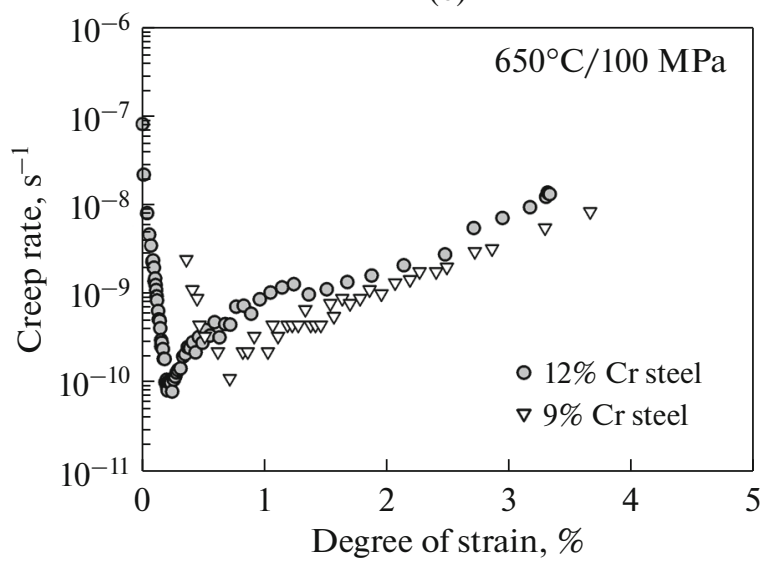

(b)

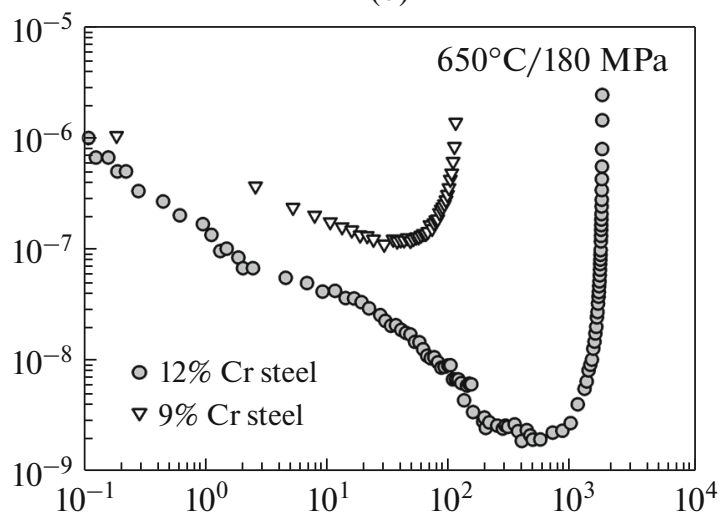

(d)

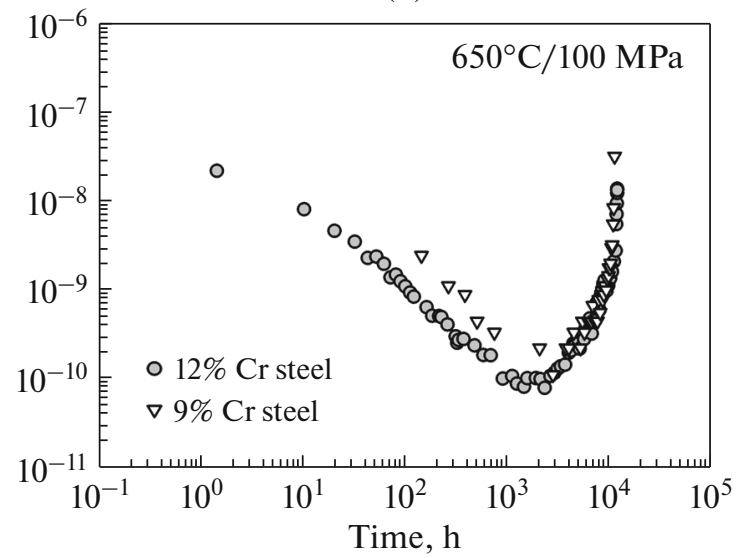

Fig. 4. Creep rate versus (a), (c) the degree of strain and (b), (d) time at a temperature of $650^{\circ} \mathrm{C}$ and applied stresses of (a), (b) 180 , and (c), (d) $100 \mathrm{MPa}$ for the studied $12 \% \mathrm{Cr}$ and $9 \% \mathrm{Cr}$ steels.

in the time of testing and the development of general processes, which make a contribution to failure of the material (coarsening of particles, transformation of the dislocation structure and substructure as a result of return).

The time to failure of the material is strongly related to the minimum creep rate at the established creep stage, and this is well described by the Monkman-Grant equation [1] (Fig. 5a)

$$
\tau_{\mathrm{r}}=\left(c^{\prime} / \dot{\varepsilon}_{\min }\right)^{m^{\prime}},
$$

where $\tau_{\mathrm{r}}$ is the time to failure of the material, $\mathrm{h}, \dot{\varepsilon}_{\min }$ is the minimum creep rate, $\mathrm{h}^{-1}$, and $c^{\prime}$ and $m^{\prime}$ are constants. For both steels, it has been found that $c^{\prime}=0.28$ and $m^{\prime}=0.69$ under all creep conditions. No evidence has been found of deviations from the linear dependence of the minimum creep rate on the time to failure of the material within a range of studied strain rates from $10^{-2}$ to $10^{-7} \mathrm{~h}^{-1}$ for both studied steels.

The dependence of the applied stress on the time to failure of the material is shown in Fig. 5b. It was revealed after creep tests that the $9 \% \mathrm{Cr}$ steel demon- strates well-defined creep strength breakdown after $2000 \mathrm{~h}$ of creep testing, whereas the long-term strength curve of the $12 \% \mathrm{Cr}$ steel has no such breakdown under the same creep conditions. In this case, the slope of the long-tern strength curve of the $12 \% \mathrm{Cr}$ steel is higher than for the $9 \% \mathrm{Cr}$ steel even after the breakdown point (Fig. 5b). A great increase in the time to failure of the material at high stresses of 200140 PMa takes place due to some advantages in the solid-state and substructural hardening of the $12 \% \mathrm{Cr}$ steel (Figs. 3 and 5b). A decrease in the applied stresses to $120-100 \mathrm{MPa}$ reduces the advantages in the hardening of the $12 \% \mathrm{Cr}$ steel to the level of the $9 \% \mathrm{Cr}$ steel, thus evidencing that the $12 \% \mathrm{Cr}$ steel has rather high structural stability, which is no worse than for the 9\% Cr steel.

To estimate the applicability of the $12 \% \mathrm{Cr}$ steel as a material for the manufacture of boiler, steam pipeline, and steam turbine blade elements, the $1 \%$ creep limit was calculated by the empirical dependence between the stress and the time required to attain the degree of strain at a level of $1 \%$ (Larson-Miller equation [1]):

$$
P=T\left(\log t_{1 \%}+36\right) \times 10^{-3}
$$


(a)

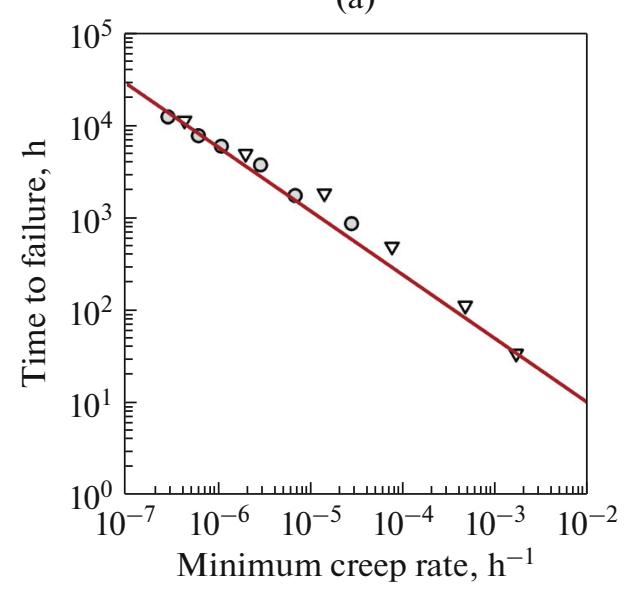

(b)

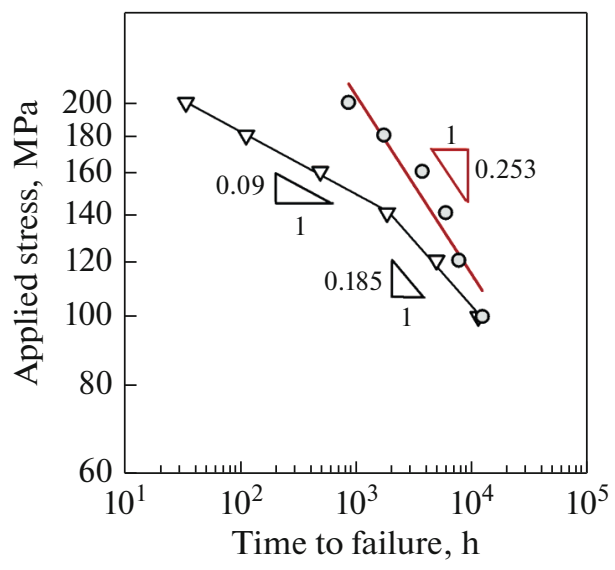

(c)

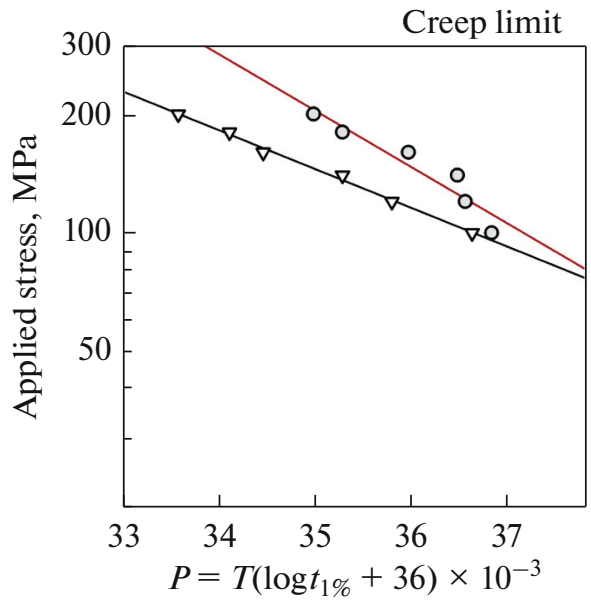

Fig. 5. (a) Minimum creep rate versus time to rupture, (b) applied stress versus time to rupture, and (c) calculation of the $1 \%$ creep limit with the Larson-Miller parameter; tests were performed at $650^{\circ} \mathrm{C}$ for the $12 \% \mathrm{Cr}(\mathrm{o})$ and $9 \% \mathrm{Cr}(\nabla)$ steels. where $P$ is the Larson-Miller parameter, $T$ is the testing temperature, $\mathrm{K}$, and $t_{1 \%}$ is the time required to attain the degree of strain at a level of $1 \%, \mathrm{~h}$. The dependences between the applied stress and the Larson-Miller parameters for the 12 and $9 \% \mathrm{Cr}$ steels are shown in Fig. 5c. The creep limit of the $12 \% \mathrm{Cr}$ and $9 \% \mathrm{Cr}$ steels is 82 and $76 \mathrm{MPa}$, respectively. The comparable creep limit values indicate that the properties of the $12 \% \mathrm{Cr}$ steel under creep are competitive with the properties of the $9 \% \mathrm{Cr}$ steel. The developed chemical composition of the $12 \% \mathrm{Cr}$ steel provides the possibility to overcome the major disadvantage of high-chromium steels, i.e., microstructural instability during creep, maximally approaching the properties of this steel under creep to the level of $9 \% \mathrm{Cr}$ steel properties.

\section{CONCLUSIONS}

The mechanical properties of the $12 \% \mathrm{Cr}$ and $9 \%$ $\mathrm{Cr}$ steel under tension and creep have been studied. The $12 \% \mathrm{Cr}$ steel demonstrates an increase in the $1 \%$ creep limit and ultimate tensile strength at 20 and $650^{\circ} \mathrm{C}$ in comparison with the $9 \% \mathrm{Cr}$ steel due to the improvement of solid-solution and substructural hardening. In the process of creep at high stresses of 200-140 MPa, a longer time to failure for the $12 \% \mathrm{Cr}$ steel is caused by a more prolonged transient creep stage. A decrease in the applied stresses reduces the distinction in the creep behavior of the $12 \% \mathrm{Cr}$ and $9 \% \mathrm{Cr}$ steels. The $1 \%$ creep limit of the $12 \% \mathrm{Cr}$ steel is $86 \mathrm{MPa}$, which evidences that the $12 \% \mathrm{Cr}$ steel under creep has high microstructural stability comparable with the stability of $9 \% \mathrm{Cr}$ steel.

\section{ACKNOWLEDGMENTS}

The authors are grateful to the Joint Research Center "Technologies and Materials" of the Belgorod National Research University for providing the equipment for mechanical tests and structural studies.

\section{FUNDING}

This study was supported by the Grant of the President of the Russian Federation for the State Support of Young Russian Scientists-Candidates of Sciences (tender MK-2019) (agreement no. 075-15-2019-1165).

\section{REFERENCES}

1. F. Abe, T. U. Kern, and R. Viswanathan, Creep-Resistant Steels (Woodhead Publishing, Cambridge, 2008), p. 800 .

2. K. Kimura, "Creep strength of high chromium steel with ferrite matrix," Int. J. Pressure Vessels Piping 87, 282-288 (2010).

3. R. O. Kaibyshev, V. N. Skorobogatykh, and I. A. Shchenkova, "New martensitic steels for fossil power plant: 
creep resistance,” Phys. Met. Metallogr. 109, 186-200 (2010).

4. R. Viswanathan and W. Bakker, "Materials for ultrasupercritical coal power plants-boiler materials: Part 1," J. Mater. Eng. Perform. 10, 81-95 (2001).

5. R. L. Klueh, "Elevated-temperature ferritic and martensitic steels and their application to future nuclear reactors," Int. Mater. Rev. 50, 287-310 (2005).

6. M. Hattestrand, M. Schwind, and H.-O. Andren, "Microanalysis of two creep resistant 9-12\% chromium steels," Metall. Mater. Trans. A. 250, 27-36 (1998).

7. A. E. Fedoseeva, P. A. Kozlov, V. A. Dudko, A. N. Belyakov, V. N. Skorobogatykh, I. A. Shchenkova, and R. O. Kaibyshev, " Microstructural changes in steel $10 \mathrm{Kh} 9 \mathrm{~V} 2 \mathrm{MFBR}$ during creep for 40000 hours at $600^{\circ}$ C," Phys. Met. Metallogr. 116, 1047-1056 (2015).

8. V. A. Dudko, A. E. Fedoseeva, A. N. Belyakov, and R. O. Kaibyshev, "Influence of the carbon content on the phase composition and mechanical properties of P92-type steel," Phys. Met. Metallogr. 116, 1165-1174 (2015).

9. A. E. Fedoseeva, N. R. Dudova, and R. O. Kaibyshev, "Effect of stresses on the structural changes in highchromium steel upon creep," Phys. Met. Metallogr. 118, 591-600 (2017).

10. P. Jauhiainen, S. Yli-Oli, A. Nyholm, P. Auerkari, and J. Salonen, "Impact of oxidation on creep life of superheaters and rehearters, creep\&fracture in high temperature components," 2nd ECCC Creep Conference (DEStech Publications, 2009), pp. 320-328.
11. I. Nikitin, A. Fedoseeva, and R. Kaibyshev, "Strengthening mechanisms of creep-resistant $12 \% \mathrm{Cr}-3 \% \mathrm{Co}$ steel with low N and high B contents," J. Mater. Sci. 55, 7530-7545 (2020).

12. H. K. Danielsen, "Review of $Z$ phase precipitation in 9-12 wt. \% Cr steels," Mater. Sci. Technol. 32, 126137 (2016).

13. D. V. Edmonds and R. C. Cochrane, "Structure-property relationships in bainitic steels," Metall. Trans. A 21, 1527-1540 (1990).

14. Q. Li, "Modeling the microstructure-mechanical property relationship for a $12 \% \mathrm{Cr}-2 \mathrm{~W}-\mathrm{V}-\mathrm{Mo}-\mathrm{Ni}$ power plant steel," Mater. Sci. Eng., A 361, 385-391 (2003).

15. C. E. Lacy and M. Gensamer, "The tensile properties of alloyed ferrites," Trans. ASME 9, 118-125 (1944).

16. G. I. Taylor, "The mechanism of plastic deformation of crystals. Part I.-Theoretical," Proc. R. Soc. A 145, 362-388 (1934).

17. F. J. Humphreys and M. Hatherly, Recrystallization and Related Annealing Phenomena, 2nd ed. (Elsevier, Amsterdam, 2004), p.658.

18. G. Langford and M. Cohen, "Strain hardening of iron by severe plastic deformation," ASM-Trans. 62, 623638 (1969).

19. J. P. Nailor, "The influence of the lath morphology on the yield stress and transition temperature of martensitic-bainitic steels," Metall. Trans. A 10, 861-873 (1979).

Translated by E. Glushachenkova 